\title{
IMPLICATIONS OF THE ORDINATION OF WOMEN FOR THE METHODIST CHURCH OF SOUTHERN AFRICA
}

\section{Luvuyo Gladstone Sifo}

University of Pretoria

luvuyosifo@gmail.com

\section{ABSTRACT}

The year 2016 marks the fortieth anniversary of the ordination of women in the Methodist Church of Southern Africa (MCSA). This, being a milestone worth celebrating and commemorating, highlights not only the gains but also the challenges that women face in the ministry of the Methodist Church. The implications of the ordination of women for the denomination (and its organisations) have yet to be fully grappled with, interpreted within the changing context of our present society, and understood in light of the patriarchal society within which the Methodist Church operates. The present article highlights the implications of the ordination of women for the Young Men's Guild - a missional organisation of men in the MCSA. The article calls for inclusive and radical transformational activity within the Young Men's Guild. It advocates for intentional implementation of the Gender Action Plan that was approved by the Methodist Conference ten years ago (2006). It agitates for a Young Men's Guild movement whose discomfort with its privilege propels it to live out the principles contained in the Methodist rule of life. Young Men's Guild members ought to actively pursue an agenda of inclusion in order for their organisation to reflect truly the vision and mission of the MCSA.

Keywords: Ordination; women; Young Men's Guild; Methodist Church of Southern Africa (MCSA)

\section{INTRODUCTION}

The year 2016 marks the fortieth anniversary of the ordination of women in the Methodist Church of Southern Africa (MCSA). The fortieth anniversary celebrations

\section{UNISA $\cong$}


were launched by the Presiding Bishop (PB) of the MCSA at the annual conference ${ }^{1}$ of the denomination held in Port Elizabeth in September 2015. In his annual address delivered at conference, PB Rev. Ziphozihle Daniel Siwa remarked that ordaining women to the ministry of the church was in obedience to God's call of first, how to be church, and second, how to do church [emphasis mine]. He called on the church to pause and praise God that our ancestors in the faith acknowledged that in Christ we are one. ${ }^{2} \mathrm{He}$ emphasised the call to celebrate and mark this milestone as follows:

I plead with the Connexion ${ }^{3}$ that we make a big deal of these moments. It is time to reflect on what God is calling us to be and to do. Let us celebrate together and be inspired to rise to greater heights of God's call on the life of the church. We plan to use the time after this Conference [2015] up to the 2016 Conference to open our eyes even more intentionally to a greater awareness of what God is doing in our midst. Our mothers, sisters and daughters are a special gift to this discipleship movement. Male and female, God created us, although the journey of the church has not been great in appreciating this gift. Now is the time to reflect, engage and take appropriate action to redress this. We are asked to showcase and celebrate the work of women ministers in a visible way. I will request the 2016 ordinands to consider including a woman presbyter among those they select. I will also appoint a woman presbyter. $^{4}$

1 The word 'Conference' refers to the annual policy and missional congress of the MCSA at which representatives from all Districts, both clergy and laity, within the Southern African Connexion of the Methodist Church are present. See Arthur F.I. Attwell, The Methodist Church: An introduction (Cape Town: Methodist Publishing House, 2005).

2 Methodist Church of Southern Africa, 2016 Yearbook (Cape Town: Methodist Publishing House, 2016), 9.

3 The term 'Connexion' (with this spelling) is used in the Methodist church to describe the denomination as a whole in a particular country or region, consisting of a number of Districts. See Neville Richardson, 'Ministerial training and theological education in the Methodist Church of Southern Africa: The road ahead', Missionalia 35:2 (2007): 137; cf Attwell, The Methodist Church; Andile M. Mbete, Iintsika zobuWesile: Amabal' engwe malunga nemvelaphi, iimfundiso kunye nemibhedesho yaseWesile (Cape Town: NF Saliwa Publishing, 2010). 
In response to this directive, all conventions ${ }^{5}$ of mission organisations ${ }^{6}$ included in their programmes an item to celebrate the ordination of women. Synods ${ }^{7}$ specifically highlighted this milestone in the life of the denomination as well. Women ministers gave testimonies of how they had experienced the journey of the past 40 years. They challenged members of the church to move swiftly towards full integration and recognition of women in ministry. Appointment of women to leadership positions was highlighted as one of the ways in which the church could demonstrate its acceptance of women in ministry. These celebrations culminated in a 'Women in Ministry Consultation' that took place in August 2016.

The fortieth anniversary of the ordination of women offers an opportunity for the MCSA to highlight not just the gains and victories, but also some of the challenges that ordained women face within the denomination. In her report to the 2015 conference, the General Secretary of the MCSA, Rev. Charmaine Morgan, made the following remarks:

Starting now, we celebrate the Year of celebrating Women Clergy. Forty years after the Ordination of the first woman as a minister, $17 \%$ of our clergy are women, $4 \%$ of our Superintendents are women, and no women are Bishops. We will celebrate our victories in the coming year in various ways, but we still have a far way to go before we can say we have achieved our goals. ${ }^{8}$

Highlighted in the General Secretary's remarks are some of the challenges that ordained women face in the MCSA, namely, prejudice, discrimination and

5 Conventions are annual gatherings of the organisations such as Young Men's Guild, Women's Manyano, Local Preachers' Association, Music Association, Order of Evangelism, Young Women's Manyano and Wesley Guild. Each year, members of these organisations meet for fellowship, accountability, spiritual inspiration, reflecting on the activities of the organisations, mission work and taking resolutions on the work of God. Conventions meet at District as well as Connexional levels.

6 Mission organisations of the church are specified in the Book of Order as: Music Association, Local Preachers' Association, Men's League, METHSSOC (Methodist Student Society), uNzondelelo, Wesley Guild, Women's Association, Women's Auxiliary, Women's Manyano, Young Men's Guild and Young Women's Manyano. See Attwell, The Methodist Church; Methodist Church of Southern Africa, The Methodist Book of Order: The laws and discipline of the Methodist Church of Southern Africa (Cape Town: Methodist Publishing House, 2014), 87.

7 Synod is an official annual gathering of the MCSA in the district of the Connexion. The MCSA is subdivided into 12 districts, namely; Cape of Good Hope, Grahamstown, Queenstown, Clarkebury, Natal Coastal, Natal West, Kimberly Namibia and Bloemfontein (KNB), Northern Free State and Lesotho (NFSL), Highveld and Swaziland, Central, Mozambique and Limpopo. See Attwell, The Methodist Church; Mbete, Iintsika zobuWesile; Methodist Church of Southern Africa, 2016 Yearbook, 21. The bishop chairs each synod. Part of Synod's business is to consider matters of discipline for members in the presbyteral and diaconate orders, receive and test the call of candidates to ministry, recommend to conference those who should be ordained, consider the reports on the mission work of the church in the district, station ministers and make resolutions regarding the work of God.

8 Methodist Church of Southern Africa, 2016 Yearbook, 21. 
oppression. After 40 years since the first woman was ordained, strategic leadership positions are still a reserve of male clergy in the MCSA. Currently, there is not a single woman who is a bishop. Out of all the ordained women, only two women hold significant positions of leadership. ${ }^{9}$ This challenge raises pertinent questions for the MCSA. The first question pertains to equality: Does the MCSA treat ordained women and men equally? The second question explores beliefs about women: Are ordained women inferior to their male counterparts? The third question addresses the issue of leadership: Are ordained women perceived as unsuitable candidates for leadership? The fourth question pertains to discrimination: Does the MCSA discriminate against ordained women? The fifth question is on oppression: Does the MCSA oppress and suppress its ordained women? This fortieth anniversary of the ordination of women offers the MCSA an opportunity to respond to these questions honestly and redress any imbalances that may be present. Regrettably, women continue to struggle against prejudices, both in society at large, as well as in the church. This article will not recite the history of the ordination of women in the MCSA. Rather, it will offer a critical reflection on the implications of the ordination of women for the Young Men's Guild, with particular reference to the Gender Action Plan and the Methodist Rule of life.

In the MCSA, as has often been the case in mission churches, ordained ministry has been a reserve only for males. According to the General Secretary's report, the majority of ministers in the MCSA are males (83\%) as compared to 17 per cent of women. ${ }^{10}$ The ordination of women 40 years ago was an attempt to challenge this situation by levelling the 'playing field' for both men and women to participate in ordained ministry equally. This was necessitated by the fact that 'the Church and the secular world in which we find ourselves today remains, as in centuries past, patriarchal and male-dominated'.${ }^{11}$ According to Venables, ${ }^{12}$ not all ministers have accepted the ordination of women in the MCSA. Women ministers have continued to suffer consequences of this resistance to their ministry. The exclusion of women ministers from certain types of ministry in the churches in which they serve; the lack of opportunities for promotion, as reflected in the male dominated hierarchy of the church; and the daily abuse and discrimination experienced by women ministers, all indicate that the oppression of women does indeed take place in the MCSA. ${ }^{13}$

9 Rev. Charmaine Morgan is currently the General Secretary of the MCSA. She is the first ever woman to hold this position in the denomination. Rev. Purity Malinga is the Director of the Education for Ministry and Mission Unit. She too, is the first woman ever to hold that position in the MCSA. Rev. Purity Malinga is the only ordained woman that has ever been a bishop in the MCSA.

10 Methodist Church of Southern Africa, 2016 Yearbook, 21; cf. Heather E. Venables, 'Women and empowerment: Strategies to achieve the liberation of women from oppression', (MTh Thesis; Pretoria: Dept. of Theological Ethics, University of South Africa, 1998), 81.

11 Venables, 'Women and empowerment', 1, 63

12 Venables, 'Women and empowerment', 38.

13 Venables, 'Women and empowerment', 39. 
Oppression of women can be seen in the various structures and organisations that form the MCSA. The focus of this article is on the Young Men's Guild, which is one of the organisations of the MCSA.

\section{Young Men's Guild (YMG)}

The Young Men's Guild (hereafter referred to as YMG) is an organisation constituted according to chapter eight of The Methodist Book of Order: The laws and discipline of the Methodist Church of Southern Africa. ${ }^{14}$ Contained in chapter 8 are rules, regulations and prescripts pertaining to units, committees and organisations of the church. Pertaining to organisations, the following reference applies:

Conference may allot part of the work of the Mission of the church at Connexional, District and Circuit level to certain Organisations established for this purpose, directing and controlling their work through Conference, the Synods or the Circuits.

The organisations are: ${ }^{15}$

- Connexional Music Association.

- Local Preachers' Association.

- Men's League.

- METHSSOC (Methodist Student Society).

- uNzondelelo.

- Wesley Guild.

- Women's Association.

- Women's Auxiliary.

- Women's Manyano.

- Young Men's Guild.

- Young Women's Manyano.

While these organisations operate in terms of their constitutions, those constitutions are subject to the prescripts contained in The Methodist Book of Order: The laws and discipline of the Methodist Church of Southern Africa, as well as other policies, decisions, practices and usages of the church. In case of conflict of interpretation,

14 The Book of Order is the constitutional manual of the MCSA. Up until 2014, it used to be called 'Laws and Disciplines.'

15 Methodist Church of Southern Africa, Methodist Book of Order, 87. 
the Laws and Discipline of the church takes precedence. ${ }^{16}$ Thus, by description, 'the YMG is an organisation of Methodist men who have accepted the calling of Jesus Christ to engage in Holistic Mission of the Church'. ${ }^{17}$ As an organisation of the MCSA, the YMG strives to embrace the mission statement of the church, which is 'to proclaim the gospel of Jesus Christ for continuous healing and transformation of the church and communities'. ${ }^{18}$

Inspired by the 1958 declaration ${ }^{19}$ of 'one and undivided church' ${ }^{20}$, the general meeting of the YMG in the Port Elizabeth Circuit (0211), sent the following proposal to the annual YMG Convention of the Grahamstown District, held in Peddie on the 21-24 April 2016: ${ }^{21}$

Women in Ministry: PE central Circuit

Whereas the Conference of 1958 declared its conviction that "it is the will of God for the Methodist Church that it should be one and undivided, trusting to the healing of God to bring this idea to ultimate fruition and that this be the general basis of our ministry and policy"22;

Whereas the MCSA ordained women to the ministry of Word and Sacraments in 1976, thus 2016 marks the $40^{\text {th }}$ anniversary of the ordination of women in the MCSA;

Whereas injustices, discrimination and rejection of women through pervasive patriarchal attitudes continue to undermine the image of God in all people, in a church that declares its full acceptance of women in ministry;

16 Methodist Church of Southern Africa, Methodist Book of Order, 87-88; cf Methodist Church of Southern Africa, Constitutions of the organisations (Cape Town: Methodist Publishing House, 2010), 92; Methodist Church of Southern Africa, Constitution of the Young Men's Guild (Cape Town: Methodist Publishing House, 2011), 1

17 Methodist Church of Southern Africa, Constitutions, 92; Methodist Church of Southern Africa, Young Men's Guild, 1; T Gqwaka, Indodana (Cape Town: Methodist Publishing House, 2016), v.

18 Methodist Church of Southern Africa, Constitutions, 92; cf. Methodist Church of Southern Africa, Young Men's Guild, 1; Methodist Church of Southern Africa, 2016 Yearbook, 2.

19 Methodist Church of Southern Africa, Methodist Book of Order, 219, 229.

20 At the height of racial segregation, division and inequality as a result of the infamous Apartheid system in South Africa, Conference 1958 made the following statement: 'The Conference declares its conviction that it is the will of God for the Methodist Church that it should be one and undivided, trusting to the leading of God to bring this ideal to ultimate fruition, and that this be the general basis of our missional policy'. Cf. Methodist Church of Southern Africa, Methodist Book of Order, 219, 229.

21 The author of this article is an ordained minister of the MCSA. He is currently stationed at PE Central Circuit (0211). He is the President of the YMG in the circuit. This proposal was drafted by a meeting of the circuit that he chaired. At the District YMG Convention, he was appointed to convene the resolutions committee where that very resolution was tabled and debated. Details of the debate and all resolutions taken at the convention will appear in the minutes of the convention and will be approved at the next convention of 2017.

22 Methodist Church of Southern Africa, Methodist Book of Order, 259. 
Notwithstanding the fact that the YMG Constitution explicitly states that the presidency of the YMG is preserved only for male clergy;

The YMG of PE Central Circuit 0211 proposes an amendment to all the clauses that exclude women ministers in the activities of the YMG, as, through their calling and ordination, they are pastors and mission leaders of the church, including church organisations.

For the first time, the superintendent minister of the Port Elizabeth Circuit (0211) is a woman. By common usage and understanding, all reports of circuits are sent to the YMG District secretary in preparation for the annual convention. The superintendent minister is deemed the person with authority to sign the report on behalf of the circuit. At the YMG District council meeting held in February 2016, it was stated by an official of the District that no woman should sign the reports of the YMG, irrespective of the office she holds in the church. This did not sit well with delegates who come from circuits that have superintendents who are women. Not only did that statement sound discriminatory, degrading and oppressive to women; it sounded as if it was questioning their ordination and authority. The proposal above came as a response to that remark. In addition, taking into consideration that the Triennial Convention $^{23}$ of the YMG would meet in May 2016 in order to, among others, revise the Constitution, Port Elizabeth Central Circuit YMG deemed it necessary to send the proposal above. The proposal sought to achieve at least three objectives, namely:

1) To challenge the remarks of the Grahamstown YMG District official regarding women superintendents.

2) To begin a conversation concerning the implications of the ordination of women by the MCSA for the YMG.

3) To address any biases against ordained women which are either implicitly or explicitly contained in the Constitution of the YMG.

The Constitution clearly states that the YMG is an organisation for men. Below are excerpts of some clauses from the Constitution: ${ }^{24}$

5.1 Only men who are full members of the Methodist Church of Southern Africa, including male ordained and student ministers, shall be received into full membership of the YMG. Every such member shall observe the provisions of this Constitution. ${ }^{25}$

23 As the name implies, Triennial Convention is a Connexional gathering of the YMG that meets every three years.

24 Methodist Church of Southern Africa, Constitutions, 92-106; Methodist Church of Southern Africa, Young Men's Guild, 1-20.

25 Methodist Church of Southern Africa, Constitutions of the organisations, 93; Methodist Church of Southern Africa, Constitution of the Young Men's Guild, 2. 
5.6 Ordained and Student Ministers who wish to belong to the YMG in accordance with paragraph 5.1 above, shall join the YMG and make a pledge to be bound by the Provisions of this Constitution prior to being robed. ${ }^{26}$

5.11 Only Ministers who are members of the YMG in accordance with the provisions of this Constitution may be part of the Leadership of the YMG. Otherwise, all other Ministers, by virtue of their pastoral status in the Church may exercise pastoral and ministerial duties and oversight to the $\mathrm{YMG}^{27}$

Concerning ministers, attendance at district meetings and conventions is stipulated in the following manner:\

10.5 All Ministers, including Student and Supernumerary Ministers in the District who are members of the YMG in accordance with paragraphs 5.1 and 5.11 above. ${ }^{28}$

Concerning the presidency of the circuit, the Constitution makes the following provisions:

11.2 The Circuit President who may be Superintendent Minister of the Circuit provided that he is a member of the YMG in accordance with paragraph 5.6 above. ${ }^{29}$

Paragraphs 11.2.1 to 11.2.3 detail provisions that should be made if the superintendent minister is not a member of the YMG and therefore cannot become the president of the circuit. ${ }^{30}$ Often, the debate concerning affording ordained women opportunities to participate fully in the activities of the YMG raises suspicion and emotions on both those in favour and those against such a proposal. Those who favour the proposal often feel that it is not adequate just to give limited recognition to ordained women as stated in clause 5.11. Those against the proposal often feel that women clergy are adequately catered for in the prescripts of the Constitution through the paragraphs referred to above. The cause of disagreement is that women ministers are excluded from participating and leading in the YMG because of their gender. The fact that clause 5.11 of the Constitution grants women in ministry a right to exercise pastoral and ministerial duties and oversight to the YMG is not enough because it grants partial recognition to ordained women. In practice, as attested to

26 Methodist Church of Southern Africa, Constitutions of the organisations, 94; Methodist Church of Southern Africa, Constitution of the Young Men's Guild, 3.

27 Methodist Church of Southern Africa, Constitutions of the organisations, 95; Methodist Church of Southern Africa, Constitution of the Young Men's Guild, 4.

28 Methodist Church of Southern Africa, Constitutions of the organisations, 101; Methodist Church of Southern Africa, Constitution of the Young Men's Guild, 12.

29 Methodist Church of Southern Africa, Constitutions of the organisations, 103; Methodist Church of Southern Africa, Constitution of the Young Men's Guild, 15.

30 Methodist Church of Southern Africa, Constitutions of the organisations, 103-104; Methodist Church of Southern Africa, Constitution of the Young Men's Guild, 15-16. 
by many ordained women, women are treated as less desirable in the YMG if they avail themselves to minister. Thus, statements like that of the district official should not be left unchallenged.

Founded in 1912, the YMG could not have envisaged a time in history where women would be ordained into ministry. ${ }^{31}$ This could possibly be one of the reasons why women in ministry are given less recognition than their male counterparts in the YMG. Marginalisation of women due to historical foundations of the YMG, pervasive patriarchal attitudes, and entrenched cultural stereotypes continue to lead to discrimination of ordained women in the YMG. Thus, the full implications of ordination of women for the YMG should be clarified. Unless this is done, rejection of women in ordained ministry will continue in the YMG under the guise of the Constitution. According to Mkhwanazi and Kgatla, women ministers continue to be rejected in the church..$^{32}$ This leads to devastating consequences such as, but not limited to: (i) women ministers losing interest in their vocation; (ii) women ministers resigning from ministry; and (iii) if they continue with ministry, most do not pursue further studies after ordination because they do not see themselves receiving recognition in spite of their further studies. This could be attributed to a number of factors such as: (i) the rejection of ordained women ministers by their male counterparts; and (ii) the African culture's depreciating view of women and use of biblical texts that support such stereotypes. Furthermore, it has been observed that men ministers do not invite ordained women to labour in their circuits. ${ }^{33}$ This leads to women ministers feeling that they are not welcome in the church. Society at large and the church in particular, are dominated by males, even though women are always in the majority in terms of numbers. ${ }^{34}$ Thus, power, control and internalised values that prevail reflect the dominant values of men, more so in an organisation such as the YMG that exclusively caters for men. Full integration of women in the life, ministry and leadership of the church has not been achieved despite the fact that the MCSA adopted a resolution to have women ordained into ministry in $1972 .{ }^{35}$ While women form the majority of membership in the MCSA, they form a very small group within the ranks of ordained ministry. ${ }^{36}$ Therefore, recognition of women is imperative because without them the MCSA is not complete.

31 Methodist Church of Southern Africa, Constitutions, 92; cf. Methodist Church of Southern Africa, Young Men's Guild, 1; Cf. Gqwaka, Indodana, v

32 Fanie S. Mkhwanazi \& Tias, Kgatla 'The place of women ministers in the mission of the Methodist Church of Southern Africa', Studia Historiae Ecclesiasticae 41(2) (2015): 181.

33 Mkhwanazi \& Kgatla '...place of women ministers', 181; cfVenables, 'Women and empowerment', 69.

34 Venables, 'Women and empowerment', 86.

35 Mkhwanazi \& Kgatla '...place of women ministers', 180.

36 Mkhwanazi \& Kgatla '...place of women ministers', 181; cf. Methodist Church of Southern Africa, 2016 Yearbook, 22-26. 


\section{Transformation for inclusiveness of women in the YMG}

In its mission statement, the MCSA declares the following: 'God calls the Methodist people to proclaim the gospel of Jesus Christ for healing and transformation. ${ }^{37}$ Thus, at the heart of Methodism is transformation. 'Transformation' is a word that is misunderstood in today's context due to overuse. The overuse of this word has rendered it meaningless in many contexts. Transformation is called for and spoken about in many sectors of society such as politics, economics, education, healthcare, sports and recreation, arts and culture, religion, civil rights movements, labour, and other sectors. The frequent use of the word 'transformation' does not necessarily mean that transformation happens in practice. While women hear the slogans of transformation in society and in church, often they see no tangible change to their situation of oppression, discrimination and rejection. While it could be easy for church leaders to talk the language of transformation and even try to act in pursuit of what they understand transformation to be, often their efforts lead to no tangible and beneficial results for oppressed women. Mkhwanazi and Kgatla warn against using 'transformation talk' in order to lull women into believing that those who use the language are serious about bringing transformation in reality. ${ }^{38}$ Transformation is a missional agenda of the church, given by God, to which all disciples are called to collaborate with God in bringing about radical change in the world. Transformation involves asking and trusting God to usher in God's reign of love, justice, righteousness, truth and peace, otherwise known as and referred to as 'God's kingdom'. In such a kingdom, there is no room for injustice, oppression, discrimination, inequality and rejection, as are often seen in the kingdoms of this world and in the church. Transformation, therefore, is a radical change of status from one way of being to another.

Understanding transformation in these terms has vast implications for the YMG, which is an exclusive organisation for men in the MCSA. Should the YMG extend its membership to include women in order for it to be transformed? What about women's organisations whose membership are gender exclusive? Should they, in pursuit of transformation, extend their membership to include men? Complicated as the answers to these questions might be, a simple response would be 'no'. However, when it comes to the recognition, participation and leadership of those who have been called and set apart for ministry through ordination, the YMG should re-evaluate its stance. While clause 5.11 of the YMG Constitution recognises that all other ministers, by virtue of their pastoral status in the church, may exercise pastoral and ministerial duties and oversight to the YMG, in practice this is not the case. In the commemoration of the fortieth anniversary of the ordination of women in the MCSA, we heard stories of ordained women barred from activities such as

37 Methodist Church of Southern Africa, 2016 Yearbook, 2.

38 Mkhwanazi \& Kgatla '...place of women ministers', 193. 
chairing YMG meetings, leading YMG events in their circuits or societies, burying YMG members, participating in the robing of YMG members, officiating at YMG activities and signing reports of the YMG. Often, the reason given for this is that they are women. Thus, ordained women continue to be victims of discrimination in the YMG because of their gender. The resolution referred to above, sent to the Grahamstown district convention of the YMG, was calling for transformation in the YMG. As an organisation of a church whose vision is to bring about transformation in the name of Jesus Christ, the YMG cannot just pay lip service to transformation. It should act intentionally and decisively in bringing about transformation of a radical kind in order for it to see the realisation of that vision. As a process, transformation in the YMG would mean actively removing all barriers - whether they be cultural, historical, ideological, constitutional, patriarchal and otherwise - for all ordained people to exercise their call of leadership and pastoral oversight over God's people, irrespective of gender and the organisation they belong to. Ordained women do not ask to be men, as many have argued; all they ask for is to be given equal respect and dignity as their male counterparts in all the organisations of the church. Like the YMG, the Woman's Manyano is an organisation that exclusively caters for black women but it recognises and acknowledges male ministers better than the YMG does to women ministers. As an ordained man, I have chaired Woman's Manyano meetings, participated in their activities, buried them and ministered to them without being made to feel inferior and unwanted among them.

Transformation is a prophetic activity that challenges the status quo of discrimination against women in the church. As a prophetic activity, it realigns the objectives and aims of the organisations of the church with the vision of the church. Transformation has positive and negative consequences. It inflicts pain to those who want to maintain the status quo and brings comfort to those who are afflicted. It brings hope to the hopeless and despair to the privileged. Men in the YMG have used masculinity as a weapon for discriminating against ordained women in the church. Mkhwanazi and Kgatla assert that transformation 'disempowers' those who were wrongly empowered and brings those who were 'disempowered' throughout history to their rightful position in the church. ${ }^{39}$ Thus, transformation is a process of radical social change in which old dehumanising practices are replaced with strategic interventions, which create new communities of God where Christ is Lord. The outcome of such transformation is a creation of a world and church where both men and women are restored to full humanity. Patriarchy and cultural stereotypes against women have had the devastating effect of removing Christ and placing frail and imperfect human beings at the centre of the universe. Discriminating against women clergy in the YMG reduces their humanity and questions their call to ordained ministry. Effective transformation in the YMG would empower the disempowered women ministers and reaffirm the image of God in each of them. Thus, according to Mkhwanazi and Kgatla, transformation that empowers brings about

39 Mkhwanazi \& Kgatla ‘...place of women ministers’, 193. 
the following: effective participation in mission, freedom, authentic partnerships, healthy relationships, transparency, self-emptying, solidarity, accountability and responsibility, equality and justice, love, peace and dignity. ${ }^{40}$ These are both outcomes of and prerequisites to empowering transformation. The YMG can only benefit if it engages itself in this kind of active and intentional transformation because 'it is only when both genders are engaged in true partnership in the mission of God that historical divisions may be addressed and corrected'. ${ }^{41}$

\section{Implementation of the Gender Action Plan}

Concerning women in the ordained ministry, the vision of the MCSA is articulated in the 'Gender Action Plan' that was tabled by the past PB Rev. Ivan Abrahams. This plan was approved by the 2006 Conference at the occasion of the thirtieth anniversary of ordination of women in the MCSA. Proposing the plan, the Rev. Abrahams asked the church to reflect on the achievements of women's empowerment and gender equality in the context of transformation as well as some of the challenges faced by the church. The conference unanimously agreed on, and hailed the plan as one of the tools that would bring lasting transformation in so far as the issue of recognition of ordination of women. Referring to Rev. Constance Oosthuizen's ${ }^{42}$ story, as one of naked prejudice and discrimination against women, he asked the following questions: ${ }^{43}$

- Do women ministers still encounter the same obstacles to enter the ministry that Constance experienced?

- Does our theological training and curriculum deal adequately with women's empowerment and gender equity?

- Why are there so few women in senior leadership positions in the church?

- Why are there not more churches, halls, pre-schools, schools and institutions named after women?

- Is our stationing process gender blind, focusing only on ability, gifts and skills?

To this effect, he, on behalf of the church, made the following confession and undertaking to women in ministry: ${ }^{44}$

\footnotetext{
40 Mkhwanazi \& Kgatla ‘...place of women ministers’, 182.

41 Mkhwanazi \& Kgatla '....place of women ministers', 193.

42 Rev. Constance Oosthuizen was the first woman to be ordained in the Methodist Church of Southern Africa, in 1976, Venables, 'Women and empowerment', 73.

43 Methodist Church of Southern Africa, Yearbook and Directory (Cape Town: Methodist Publishing House, 2007), 5.

44 Methodist Church of Southern Africa, Yearbook and Directory (Cape Town: Methodist Publishing House, 2007), 5.
} 
Forgive us where we have failed you or taken your contribution to the life and witness of the church for granted. I [sic] wish to place on record today my [sic] commitment to gender transformation and I [sic] call on the church to develop and implement a Gender Action Plan that will seek to inter alia:

- Eliminate gender biases in our current policies.

- Set clear equity targets to ensure equal participation of men and women in decision making.

- Develop Bible studies and leadership programmes for institutional transformation.

- Reflect on the critical role and participation of men in gender equality.

The fortieth anniversary of the ordination of women in the MCSA offers the denomination a unique opportunity to evaluate the impact of the implementation of that Gender Action Plan. This anniversary occasions a reflection of whether or not the denomination has been able to eliminate gender biases in its current policies. With particular reference to the YMG, the question of whether or not men are active participants in ensuring gender equality begs an answer. The question of meaningful and equal participation of ordained women in the decision-making processes of the church should be reflected on. The proposal of the PE Central Circuit (0211) to the YMG convention of Grahamstown District was inspired by this Gender Action Plan. Gender biases, as seen in the clauses of the YMG Constitution and attested to in the stories of many ordained women, continue to dictate the nature of the business and mission of the YMG. Notwithstanding the fact that the YMG is an organisation of men, ministry to the YMG should not be limited to one gender. According to Genesis 1:27, God created both male and female in God's own image and likeness and gave equal authority for stewardship to both of them. ${ }^{45}$ Thus, gender is part of what it means to be created in the image of God. Therefore, skills, gifts and abilities of both male and female should be valued, utilised and appreciated equally. ${ }^{46}$ Restricting women who are called to serve in God's mission based on their femininity is, therefore, against God's intended purpose of creation. This fortieth anniversary of the ordination of women calls for the YMG to put into practice the Gender Action Plan that was approved 10 years ago by the MCSA conference. Putting it into practice would mean measuring its [YMG] Constitution, practices and activities against the objectives of the Gender Action Plan. Critical for the YMG is conducting an honest evaluation based on the questions of whether it continues or not to discriminate against ordained women. A transformational YMG movement that is part of a church that celebrates a milestone as this, has to answer the following questions:

45 cf Methodist Church of Southern Africa, 2016 Yearbook, 9.

46 Mkhwanazi \& Kgatla '...place of women ministers', 193. 
(i) Does the YMG continue to put obstacles so that women may not exercise their ministry both in the organisation and in the church? This question begs a thorough reflection and honest feedback on whether the YMG has made it easy or more difficult for women to respond to their call, enter ministry and exercise their call meaningfully. If today, women still encounter the same obstacles as the first woman ${ }^{47}$ to be ordained in the MCSA, then not much progress has been made towards transformation. For true transformation to happen, the YMG should be removing instead of putting obstacles in the way of ordained women, hence the call to revise the Constitution.

(ii) To what extent does the YMG contribute to sound theological training, deep spiritual formation and effective vocational readiness for both men and women who feel called to ministry? Often, it has been stated that women are not ready to lead both in society and in the church. ${ }^{48}$ This is an excuse that has been given by those who perpetuate discrimination against women. If leadership in the YMG is reserved only for men, how would women ever gain exposure, experience and skill in leading if they are not given an opportunity to lead an organisation as big as the YMG? Who, then, is to blame if women are never ready to lead under such circumstances? Certainly, the blame cannot be on the shoulders of women who are oppressed and marginalised, but on the shoulders of the church and organisations that reserve opportunities of leadership only for men. For as long as women are side-lined from leading, they will always be seen as not ready. The question of few women in senior leadership positions in the church can be attributed to, among others, lack of available opportunities for women to exercise leadership. Transformation in the YMG means actively opening up and intentionally availing opportunities for ordained women to lead. The resolution of the PE Central Circuit (0211) to the YMG district convention intended to conscientise the YMG to this reality.

(iii) To what extent does the YMG contribute towards just placement of women in stations across the Connexion? An accidental stationing process can only cause damage to women. If today, women are still not invited into circuits but depend on being sent to stations by conference, it means that the MCSA has not made much progress in addressing gender imbalances in the ranks of its ministers. Statements of YMG officials to the effect that no women should sign YMG reports contribute to discrimination against women. Circuit stewards might not feel at liberty to invite an ordained woman because she will have partial authority over the affairs of the church. If she cannot chair certain meetings or conduct certain business when it comes to organisations, the circuit may find itself naturally gravitating towards men when it considers ministers for invitations. Transformation in the YMG means revisiting those clauses that implicitly result in discrimination against women.

47 The first woman to be ordained in the MCSA was Rev. Constance Oosthuizen in 1976.

48 Ndikho Mtshiselwa, 'Reconstructing a Deuteronomistic Athaliah in the (South) African context: A critique of the patriarchal perception of women', Verbum et Ecclesia 36/1 (2015): 1-8. 
(iv) Does the general membership of the YMG appreciate the full ramifications of the exclusive clauses of their Constitution on ordained women? If they do, what are they doing about it? Are they so comfortable with their position of privilege to such an extent that they do not want to see transformation take place in their organisation? Transformation of any kind brings discomfort because it challenges the status quo. The fortieth anniversary of the ordination of women offers a unique opportunity for the men in the YMG to repent of their failure to challenge ideological, constitutional and systemic discrimination against women in the organisation. In 2006 as well as in 2015, the presiding bishops of the MCSA confessed to women in ministry the failure of the church to take seriously and act expediently on gender transformation. While the church, through its leaders, confesses and takes responsibility for discrimination, oppression and biases against women, it would seem that Methodist people on the ground do not take these confessions seriously. Thus, the YMG remains stereotypical in its approach to ordained women.

The Gender Action Plan asks very serious questions of the church as well as organisations within the church to turn around the status quo. Unless the YMG answers these questions honestly and acts towards changing the status quo, it cannot claim to be actively pursuing transformation. Ordination of women implies that the YMG puts into practice the Gender Action Plan.

\section{Living by the Methodist rule of life}

Profession of theological tenets, dependence upon traditional ritual or ecclesiastical authority are not the foundations upon which membership in the MCSA is based. The Methodist Book of Order: The laws and discipline of the Methodist Church of Southern Africa, states that membership is based upon: ${ }^{49}$

...a personal experience of the Lord Jesus Christ, brought about by the Spirit, ranging from the earliest signs of Divine Grace in the soul to its crowning blessedness in the joy of "perfect love", and upon a sharing of such gifts of grace with others seeking or enjoying a similar experience.

Thus, the spirit and practice of Christian love is an indispensable condition of faithful membership in the Methodist Church. ${ }^{50}$ In living and expressing the spirit of Christian love, Methodists are encouraged to observe the threefold Methodist rule of life, which contains the obligations of (i) doing no harm, (ii) doing good, and (iii) attending upon the ordinances of God. ${ }^{51}$ For Methodists, 'doing no harm'

49 Methodist Church of Southern Africa, Methodist Book of Order, 25; cf Mkhwanazi \& Kgatla '... place of women ministers', 194.

50 Methodist Church of Southern Africa, Methodist Book of Order, 25; cf Mkhwanazi \& Kgatla '... place of women ministers', 194.

51 Rueben Job, Three simple rules: A Wesleyan way of living (Nashville: Abingdon Press, 2007); N T. Oosthuizen, A simple rule of life (Eikenhof: Upper Room Ministries, 2010); Methodist Church of Southern Africa, Methodist Book of Order, 25; cf Mkhwanazi \& Kgatla '...place of women ministers', 194. 
entails avoiding evil of every kind, especially that which is more generally practised. 'Doing good' entails being merciful after one's own power, doing good of every possible sort to the bodies of people, as well as to their souls. 'Attending upon the ordinances of God' entails participating in public worship, observing the Lord's Supper, maintenance of Christian community, private prayer, reading the scriptures and engaging in habits of self-discipline. In his book 'And are we yet alive', Peter Storey refers to Methodists as Wesleyan Christians. He describes Wesleyan Christians as follows:

Wesleyan Christians are those who grow from Baptism through the experience of the warmed heart into lives of disciplined love for God and neighbour, expressed in acts of devotion and worship, compassion and justice, and are willing to be held accountable to this by their fellow believers. Wesleyan Christians take an intentional option to stand with the poor and marginalised of society, against the principalities and powers that hold such in bondage, declaring the Good News of Jesus by word and deed. ${ }^{52}$

The description above sums up the Methodist rule of life. Love for God and neighbour is central in our understanding of who a Methodist is, hence the practice of Christian love becomes a condition for Methodist membership. It is against this backdrop that the present article examines the implications of the ordination of women for the YMG in the MCSA. The law of love is the law of Christ for all disciples. It should be the foundation upon which the theology, vision and mission, and by extension, all attendant practices, values, principles and Constitution of the YMG are built. Therefore, it is expected of YMG members who live according to this 'rule' to engage in a struggle of eliminating any prejudices and discrimination against women in the church. In so doing, they would be following the example of their Lord and Master. Discrimination, for whatever reason, causes harm to those who are discriminated against. This fortieth anniversary of the ordination of women offers the YMG an opportunity to go back to basics. Revision of the Constitution in favour of the inclusion of women is a step in the direction of doing good, not only for the women concerned, but also for the YMG and the wider church. Male members of the YMG cannot continue to negate the responsibility of being activists against any practice or ideology that is oppressive to women. Thus, the proposal of the PE Central Circuit YMG to the convention of Grahamstown District was a call for every YMG member to live according to the Methodist rule of life. Living according to the Methodist rule of life, means reclaiming Wesleyan Christianity within the YMG. The initial step towards responding to that call is revising every clause in their Constitution that perpetuates discrimination against ordained women in the MCSA. As Peter Storey declares: ${ }^{53}$ "The Methodist movement, at its best,

52 Peter J. Storey, And are we yet alive? Revisioning our Wesleyan heritage in the new southern Africa (Cape Town: Methodist Publishing House, 2004), 46.

53 Peter J. Storey, And are we yet alive? Revisioning our Wesleyan heritage in the new southern Africa (Cape Town: Methodist Publishing House, 2004), 17. 
offered, and should still offer, an authentically scriptural, radically transformative, intentionally practical way of doing the Gospel, practising being disciples, becoming more like Jesus, living the great commandments of God, finding healing in our own lives and in God's world.'

\section{CONCLUSION}

The reflection of the present article was inspired by the fortieth anniversary of the ordination of women in the MCSA. The ordination of women did not only usher a 'new dispensation' into the denomination, it challenged the very foundations upon which the theology and practical outworking of the values held by the YMG were based. The YMG, an organisation for men in the Methodist Church, has a responsibility of removing barriers for women to exercise their call freely within the church. At the forefront of removing those barriers is the intentional act of revising its Constitution so that it affords ordained women full participation in its life and mission. Radical transformation of the YMG as an organisation is, therefore, necessary if inclusion of ordained women is to be achieved. As such, this article has argued that the ordination of women in the MCSA has implications, not only for the denomination, but for all its departments and organisations, particularly the YMG. Those implications include working for transformation, applying the Gender Action Plan and living according to the Methodist rule of life.

\section{Declaration of competing interests}

The author declares that he has no financial or personal relationships with any person, institution or business, which may have inappropriately influenced him in writing this article.

\section{REFERENCES}

Attwell, A.F.I. 2005.The Methodist Church: An introduction. Cape Town: Methodist Publishing House.

Gqwaka, T. Indodana. Cape Town: Methodist Publishing House, 2016.

Job, R.P. 2007. Three simple rules: A Wesleyan way of living. Nashville: Abingdon Press, 2007.

Mbete, A.M. 2010. Iintsika zobuWesile: Amabal' engwe malunga nemvelaphi, iimfundiso kunye nemibhedesho yaseWesile. Cape Town: NF Saliwa Publishing.

Methodist Church of Southern Africa. 2007. Yearbook and directory. Cape Town: Methodist Publishing House.

Methodist Church of Southern Africa. 2010. Constitutions of the organisations. Cape Town: Methodist Publishing House. 
Methodist Church of Southern Africa. 2010. Constitution of the Young Men's Guild. Cape Town: Methodist Publishing House.

Methodist Church of Southern Africa. 2014. The Methodist Book of Order: The laws and discipline of the Methodist Church of Southern Africa. Cape Town: Methodist Publishing House.

Methodist Church of Southern Africa. 2016 Yearbook. Cape Town: Methodist Publishing House.

Mkhwanazi, F.S. \& Kgatla, T. 2015. The place of women ministers in the mission of the Methodist Church of Southern Africa. Studia Historiae Ecclesiasticae 41(2): 180-197.

Mtshiselwa, N. 2015. Reconstructing a Deuteronomistic Athaliah in the (South) African context: A critique of the patriarchal perception of women. Verbum et Ecclesia 36(1): 1-8.

Oosthuizen, N.T. 2010. A simple rule of life. Eikenhof: Upper Room Ministries.

Richardson, N. 2007. Ministerial training and theological education in the Methodist Church of Southern Africa: The road ahead. Missionalia 35(2): 131-152.

Storey, P.J. 2004. And are we yet alive? Revisioning our Wesleyan heritage in the new southern Africa. Cape Town: Methodist Publishing House.

Venables, H.E. 1989. Women and empowerment: Strategies to achieve the liberation of women from oppression. MTh Thesis; Pretoria: Dept. of Theological Ethics, University of South Africa. 